\title{
Street Vendors an Informal Enterprise - A Socio Economic Overview
}

\author{
Kampasati Veeraiah* \\ Department of Political Science, Osmania University, Hyderabad, Telangana, India \\ *Corresponding author
}

\section{A B S T R A C T}

\section{Keywords}

Street vendors, Informal Enterprise, Socio Economic status

\section{Article Info}

\section{Accepted:}

22 April 2021

Available Online: 10 May 2021
A street vendor is an individual who deals with goods or services for transaction to the public without having a permanent set space but with a temporary or immobile structure or mobile stall. It includes an important basis of livelihood for nearly $2.5 \%$ of Indian population in urban and semi urban areas. They sell everything from fresh vegetables to prepared foods, building materials to garments and crafts. Their role in the urban and semi urban areas is expanding market opportunities and street vending is gaining an important role in the urban development. Inspite of playing an important role in informal sector they never gained proper recognition. The present study made an attempt to take a clear picture of present conditions of existing street vendors in urban areas of GHMC. The results revealed that highest percentage (74\%) of street vendors belong to the age group between 31-40 years. Majority (68\%) street vendors were having only secondary level of education ie. 10 th standard. Out of 50 street vendors( 88 per cent) are having business as their family occupation and were married. Out of five types of street vendors fruit selling vendors are found to have highest (76\%) membership in the CIGs (Common Interest groups) followed by chat vendors (72\%) and mini meals vendors are the least (24\%)to have membership in the CIGs. While coming to the part of loan accessibility fruit selling vendors are the most (46\%) loan availed street vendors and mini meals vendors were least (16\%) loan availed street vendors. Hence the study claims to focus on present position of street vendors to mitigate methodologies in view betterment of financial approaches to safeguard their livelihood and make this profession more profitable and respectable.

\section{Introduction}

A self-employed vendor is a microentrepreneur who earns his living by selling products or services on the streets without any permanent structure to make his transactions. It provides possibility to the deprived to sustain their life through small earning. Street vending provides livelihood and source of income to a huge section of population. Approximately $2.5 \%$ of India's total population makes street vending as important basis of livelihood in urban and semi urban areas. Kasmad and Alwi (2015) stated that street vendors are a group of people who are engaged in small-scale business and 
vulnerable to poverty. They are engaged in sale of fresh vegetables to prepared foods, building materials to garments and crafts. Their role in the urban and semi urban areas is expanding informal employment with less investment as well market opportunities.

It is gaining an important role in the urban development and retail marketing. Inspite of playing an important role in informal sector they never gained proper recognition.

They struggle for legal recognition for the social and economic contributions for their profession and their moans have received very little attention from policy makers. Hence an attempt was made to focus on present position of street vendors existing in urban areas of GHMC to mitigate methodologies in view betterment of financial approaches to safeguard their livelihood and make this profession more profitable and respectable.

Kumar, R and Singh, A (2009) stated that the street vendors were belonging to the unorganized sector of the society and government has form the organizations like Self Help Groups (SHGs), Cooperatives and other forms through banks to facilitate the empowerment of the street vendors. It also manages the financial facilities to them.

Maheswari, N(2017)positively said that innovative partnership model for developing model markets for street vendors was indeed a pioneering step in securing the livelihood of the street vendors and their families.

Satyam, S. S (2008) made an attempt to consolidate street vending into legislation in 2004 with the formulation of the 'Street Vendors Policy'. The Policy aimed to grant street vendors legal status and allow them to carry out their business in designated areas known as hawker zones and no hawker zones. Assan, J.K and Chambers, T (2014)revealed that the diversified forms of labour organisation was existed even though it was often reactive and limited to areas with a well established vending community. Therefore, the researcher proposed that more attention should be given to labour in the informal sector and that those in such occupations should be recognized and protected by national and state laws as workers with labour rights.

Syamsir (2015) explored that the Government running quite well through bringing them under collective action plans of community development and the level of success of the street vendor's empowerment programs. During the time was categorized as quite well, especially when it was measured based on capital movement of the street vendors.

Richa, S., Deepanshu, $M$ and Sanjana, M (2019)has stated that the increasing dependence on street vending was a major source of livelihood for people across urban spaces in countries like Cambodia and India

Bhowmik, S. K and Saha, D (2012)studied on a broad and holistic approach, which was needed to ease the problem to develop common places for street hawkers for their trading activities while formulating urban plans and also explored that it was necessary to take into account the right of hawkers to public space.

\section{Materials and Methods}

Greater Hyderabad Municipal Corporation (GHMC) is one of the largest municipal corporations in India with a population of 6.9 million, encloses large number of street vendors. It was selected purposively for the present investigation. The research was carried in five circles belonging to the East Zone of GHMC namely Uppal, Kapra, L.B.Nagar, Haythnagar and Saroornagar urban local 
bodies where street vending is done vastly. Ten active street vendors were taken as a sample from each circle comprising of total sample. A total number of 50 samples were selected purposively from the selected locale. Data was collected by interviewing the street vendors personally through a detailed interview schedule. The study dealt with five types of vendors including fruit sellers, snack foods, flowers and non perishable items. The responses were categorized, quantified, scored and tabulated using descriptive statistics for analyzing the data to determine the socio economic status of the street vendors.

\section{Results and Discussion}

The results of the present study was presented and tabulated below in detail.

From the Table 1, the results revealed that majority $(74 \%)$ of the street vendors were belonging to the age group between 31-40 years whereas 68 per cent of the street vendors were completed their secondary level of education i.e. $10^{\text {th }}$ standard. Out of the total street vendors, more than three-fourth per cent of the street vendors were males who are into street vending and nearly one-fourth percent $(24 \%)$ of street vendors were females showing less significance of women street vendors in India.

The results were in line with Dr. N. Maheswari, Tiruchirappalli district stating that women street vendors played an important role in informal sector but not gained proper recognition. As per family occupation, 88 per cent of the street vendors were having business followed by farming (10\%) and government or private employee $(6 \%)$. More than half of the street vendors $(56 \%)$ of them belonging to $\mathrm{OBC}$ category while only 6 per cent were belonging to OC category. Eight four per cent of the street vendors were married.
Different types of street vending activities practised by the street vendors in all five circles from East Zone of GHMC were studied in Figure 1.

Highest percentage of the street vendors were performing vending activities as per the selected circles were found i.e. 36 per cent and 24 per cent were performing fruit juice vending sale activity in Uppal and Hayathnagar circles followed by 46 per cent and 24 per cent were performing whole fruit vending sale activity in L.B Nagar Circle and Kapra circles, this may be due to presence of wholesale fruit market in those selected areas. Twenty eight per cent were performing mini meals sale activity in Saroornagar circle.

Lowest percentage of the street vending activities were found in all five circles were 6 per cent and 10 per cent of the street vendors were performing chat/panipuri sale activity in Uppal and Saroornagar circles, 6 per cent were performing whole fruit vending sale activity in L.B. Nagar circle and8 per cent, 12 per cent,14 per cent of the street vendors were performing mini meals activity in L.B. Nagar, Kapra and Hayathnagar circles.

From fig. 2, results of the study revealed that majority of the street vendors were having membership in CIGs according to their street vending sale activities such as fruit (whole) (76\%) followed by chat/panipuri (72\%), fruit juice stall $(64 \%)$, Tea stall $(58 \%)$ whereas 76 $\%$ of the street vendors does not have membership in CIGs according to the vending sale activity i.e., mini meals (24\%).

Street vendors were taken loan as per the vending activity were studied in Table 2 . The findings of the study explored that fruit (whole) vending activity had taken loan 46 per cent followed by chat/panipuri vending activity (42\%), fruit juice stall (28\%), tea stall $(26 \%)$ and mini meals $(8 \%)$. 
Table.1

\begin{tabular}{|c|c|c|}
\hline \multicolumn{3}{|c|}{ Selection of street vendors as per the circles } \\
\hline Name of Zones & Name of Circles & Sample \\
\hline East Zone & L B Nagar & 10 \\
\cline { 2 - 3 } & Uppal & 10 \\
\cline { 2 - 3 } & Kapra & 10 \\
\cline { 2 - 3 } & Hayathnagar & 10 \\
\cline { 2 - 3 } & Saroornagar & 10 \\
\hline
\end{tabular}

Table.2 Personal characteristics of Street vendors existing in GHMC areas

\begin{tabular}{|c|c|c|c|c|}
\hline & & & & $\mathrm{N}=50$ \\
\hline S. No & Attributes & Options & Frequency (N & Percentage $(\%)$ \\
\hline \multirow[t]{4}{*}{1.} & \multirow[t]{4}{*}{ Age (years) } & $15-20$ & 2 & 4.00 \\
\hline & & $21-30$ & 9 & 18.00 \\
\hline & & $31-50$ & 37 & 74.00 \\
\hline & & 51 and Above & 2 & 4.00 \\
\hline \multirow[t]{2}{*}{2.} & \multirow[t]{2}{*}{ Gender } & Male & 38 & 76.00 \\
\hline & & Female & 12 & 24.00 \\
\hline \multirow[t]{8}{*}{3.} & \multirow[t]{8}{*}{ Education } & Illiterate & 3 & 6.00 \\
\hline & & Primary & 10 & 20.00 \\
\hline & & Secondary & 34 & 68.00 \\
\hline & & High school & 1 & 2.00 \\
\hline & & Intermediate & 2 & 4.00 \\
\hline & & Under Graduate & -- & -- \\
\hline & & Post Graduate & -- & -- \\
\hline & & Ph. D & -- & -- \\
\hline \multirow[t]{3}{*}{4.} & \multirow{3}{*}{$\begin{array}{c}\text { Family } \\
\text { Occupation }\end{array}$} & Farming & 5 & 10.00 \\
\hline & & Business & 44 & 88.00 \\
\hline & & Govt /Pvt. employee & 3 & 6.00 \\
\hline \multirow[t]{4}{*}{5.} & \multirow[t]{4}{*}{ Caste } & $\mathrm{OC}$ & 3 & 6.00 \\
\hline & & $\mathrm{OBC}$ & 28 & 56.00 \\
\hline & & $\mathrm{SC} / \mathrm{ST}$ & 12 & 24.00 \\
\hline & & Minorities & 7 & 14.00 \\
\hline \multirow[t]{4}{*}{6.} & \multirow[t]{4}{*}{ Marital Status } & Married & 42 & 84.00 \\
\hline & & Unmarried & 3 & 6.00 \\
\hline & & Divorce & 2 & 4.00 \\
\hline & & Widow & 3 & 6.00 \\
\hline
\end{tabular}


Table.3 Distribution of street vending sale activity according to the loan taken

\begin{tabular}{|c|c|c|c|c|}
\hline \multirow{2}{*}{ Type of street vendors } & \multicolumn{2}{|c|}{ Yes } & \multicolumn{2}{c|}{ No } \\
\cline { 2 - 5 } & F & $\%$ & F & \% \\
\hline Chat/Panipuri & 21 & 42 & 29 & 58 \\
\hline Fruit (Whole) & 23 & 46 & 27 & 54 \\
\hline Tea Stall & 13 & 26 & 37 & 74 \\
\hline Fruit Juice Stall & 14 & 28 & 36 & 72 \\
\hline Mini Meals & 8 & 16 & 42 & 84 \\
\hline
\end{tabular}

Table.4 Average amount of total loan

\begin{tabular}{|c|c|}
\hline $\begin{array}{c}\text { Type of Street } \\
\text { Vendors }\end{array}$ & $\begin{array}{c}\mathrm{N}=50 \\
\text { Average used for the activity for which loan } \\
\text { was taken }(\%)\end{array}$ \\
\hline Chat/Panipuri & 100.00 \\
\hline Fruit (whole) & 96.00 \\
\hline Tea Stall & 76.00 \\
\hline Fruit Juice Stall & 69.00 \\
\hline Mini Meals & 57.00 \\
\hline
\end{tabular}

Fig.1 Distribution of street vending sales activity in East Zone of GHMC

\begin{tabular}{|r|r|r|r|r|r|}
\hline \\
Uppal \\
L B Nagar
\end{tabular}


Fig.2 Distribution of street vendors as per membership in CIGs according to their vending sales activity

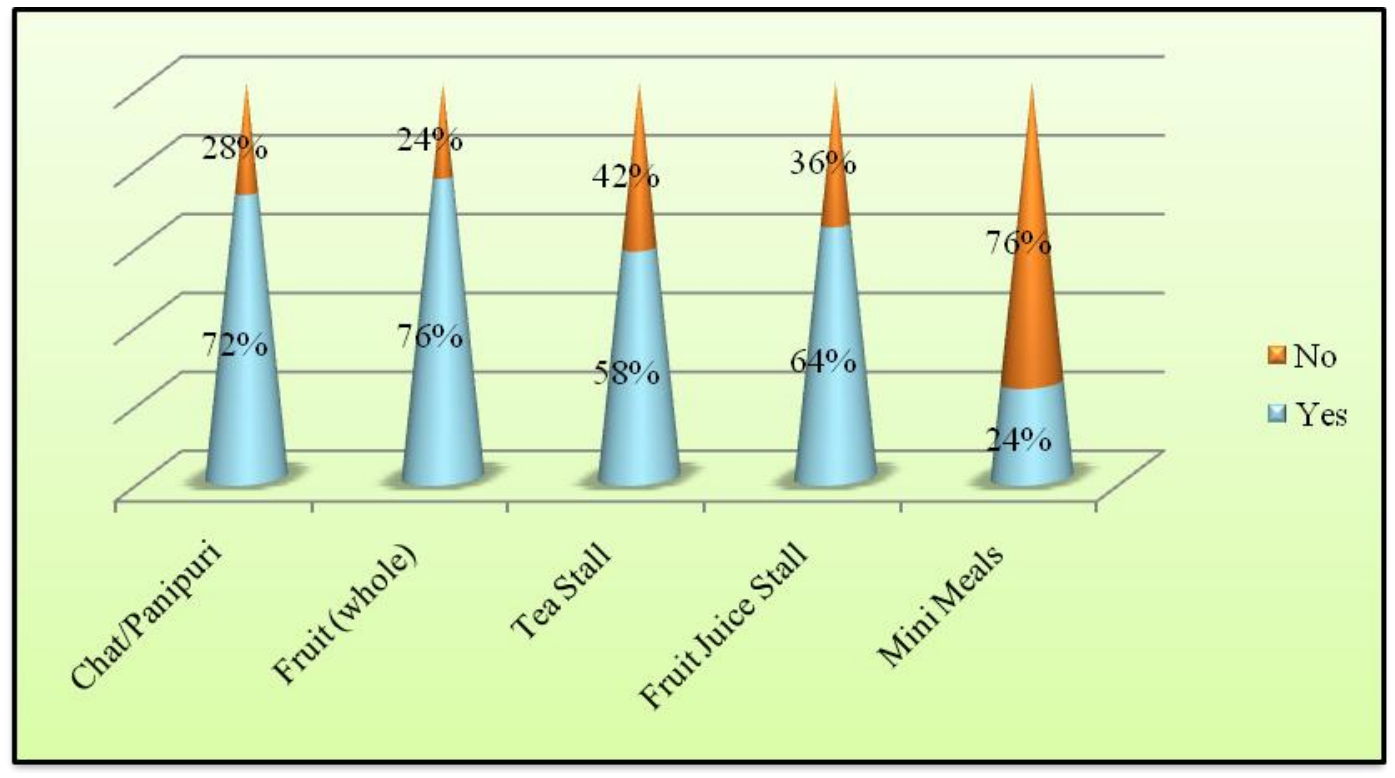

This may be due to the reason of the positive approach and awareness created by the gross root level administrators of the policies.

Table 3 depicts that Cent per cent of the street vendors were used the loan for the selected activity i.e., chat/panipuri (100\%) whereas 96 per cent of them were used for fruit selling vending activity followed by tea stall (76\%), fruit juice stall $(69 \%)$ and mini meals vending activity $(57 \%)$. Bringing the unorganised sector of street vendors into single frame could initiate financial support from stake holders and increasing the collective buying capacity of the vendors which was reported by Randhir Kumar and Arbind Singh in their study for empowering the street vendors in changing Indian cities.

In conclusion, the outcomes of this study indicate that among highest percentage of street vendors belong to the age group between 31-40 years. Majority of street vendors were having only secondary level of education. Out of the total street vendors most of them were seemed to be males who are into street vending activities. Fruit juice stall was the most practiced street vending activity in Uppal, while Chat and fruit (whole) selling was the least practised street vending activities. In context of L B Nagar circle fruit (whole) fruit sellers were most found street vendors. While coming to the part of loan accessibility fruit selling vendors are the most (46\%) loan availed street vendors and mini meals vendors were least (16\%) loan availed street vendors. Street vending has become an essential enterprise activity of few deprived communities. Though the government has facilitated the empowerment of street vendors still it is required to give importance in planning developmental policies towards upliftment of street vendors. The research will benefit the street vendors 'policy planners and administrators.

\section{References}

Kumar, R and singh, A. 2009. Empowering the street vendors in changing Indian cities - a case study of Bhubaneswar 
(Orissa).

http://www.foxitsoftware.com.

Maheswari, N. 2017. Astudy on the socio economic status of women street vendors with reference to Tiruchirappalli district. Project report no. f.mrp-6472/16(sero/ugc), link no. 6472 .

Satyam, S. S. 2008. National policy for urban street vendors and its impact. Ecologyand policy. 22, 23.

Assan, J.K. and Chambers, T. 2014. India's street vendors and the struggle to sustain their livelihoods and informal enterprises: unionization, political action and sustainable development. International journal of development and sustainability. 3(11). 2140-2161.

Kasmad, Rulinawaty and Alwi. 2015. Democratic model of public policy accountability: case study on implementation of street vendors empowerment policy in makassar city. Journal of government and politics. 6 .
Syamsir. 2015. The empowerment of marginalized community (street vendors) for developing creative economy in payakumbuh city west sumatra, http://dx.doi.org/10.18196/jgp.2016.00 23 79-103.

Richa, S., Deepanshu, M andSanjana, M. 2019. Street vending in urban 'informal' markets: reflections from case-studies of street vendors in Delhi (India) and phnom penh city (cambodia) journal homepage: www.elsevier.com/locate/cities,vol 89:120 - 129.

Bhowmik, S. K and Saha, D. 2012. Street vending in ten cities in India. Delhi national association of street vendors of India; www.streetnet.org.za/docs/research/20 12/en/nasvireport-survey.pdf. www.wiego.org > occupational-groups groups $>$ street-vendors

\section{How to cite this article:}

Kampasati Veeraiah. 2021. Street Vendors an Informal Enterprise - A Socio Economic Overview. Int.J.Curr.Microbiol.App.Sci. 10(05): 587-593.

doi: https://doi.org/10.20546/ijcmas.2021.1005.066 